Article

\title{
The Dynamics of Urban Land Rent in Italian Regional Capital Cities
}

\author{
Benedetto Manganelli * (1) and Beniamino Murgante \\ School of Engineering, University of Basilicata, Viale dell'Ateneo Lucano 10, 85100 Potenza, Italy; \\ beniamino.murgante@unibas.it \\ * Correspondence: benedetto.manganelli@unibas.it; Tel.: +39-0971-205-171
}

Received: 20 July 2017; Accepted: 18 August 2017; Published: 22 August 2017

\begin{abstract}
This research tries to interpret the results of the empirical analysis of urban land value variations from 1977 to 2012 in the regional Italian capital cities based on the well-known theory of urban land rent. The historical series to be analyzed were obtained as the difference between the market value of a property and its cost of production. The paper shows, in quantitative terms, how differential and absolute rents will be translated into the dynamics of land values in relation to local specificities. The analysis of urban land rent evolution and the comparative study of the phenomenon compared to urban geography highlighted the difference among the various urban systems investigated and the criticalities generated by processes of transformation that have affected some Italian urban contexts. The difference is essentially explained by the different weight of macroeconomic variables, related to national and international contexts, and microeconomic variables, closely related to local demand and supply, in the process of rent formation.
\end{abstract}

Keywords: urban land rent; real estate market; urbanization

\section{Introduction}

Based on a historical series of property values and production costs of buildings from 1977 to 2012, this study analyses the dynamics of the urban rent of residential land in the 19 regional Italian capital cities, distinguishing three concentric zones: the centre, the semi-centre, and the suburbs. Empirical observation of trends shows common aspects and differences. The similarities and differences that can be observed between cities and between parts of cities are the object of the analysis of this work, which attempts to provide a theoretical interpretation of them only on the basis of the well-known theories about urban rent. More particularly, the phenomena of absolute and differential rent are evident. The comparison between the different observed dynamics allowed justified them, in some cases in relation to general macroeconomic phenomena, and in some cases in relation to well-known and particular local context situations.

The analysis of real estate value dynamics should be developed starting from the analysis of land rent. In classical approaches, rent is the remuneration of a scarcely productive factor (land). Smith [1] considers rent, such as the remuneration of the 'land' production factor, which exists as long as the price of produced goods exceeds the sum of wages and profits. It is, therefore, an effect and not the cause of the price level, which is strongly affected by demand, because of supply rigidity. Therefore, demand is the main generator of rent.

Ricardo [2] defines the rent as a function of a different land productivities and, consequently, of an existing differential in production costs.

The theory of diminishing returns justifies a lesser cultivation of fertile cropland as the result of a growing demand of agricultural products; this corresponds to rising costs of production. 
The selling price of goods produced on marginal (less fertile) lands, defined by production costs, generates different levels of rent for landowners of the most fertile lands who, therefore, sustain a lower production cost. Therefore, agricultural product supply generates rent.

According to Ricardo, the supply of these goods, in contrast to other goods, that in the classical theoretical economic model have constant average production costs with increasing production is, however, increasing: "the amount of land is not unlimited and the quality is not uniform".

Extending this concept of differential rents, Von Thunen [3] provides a model in which the residual value of rent depends on the differential production cost, which also includes transportation costs.

Marx, instead, attributed to rent a genesis essentially related to the presence of monopolistic conditions [4].

Owning and accumulating natural resources with a particular value of fertility (limited resources not accessible to everybody), can generate a residual income (surplus) destined to compensate landowners.

The scheme defines a rent from a dominant position and market failures and, therefore, focuses the attention on exchange relations between economic subjects.

Despite supply always determining surplus, i.e., the difference between the availability to pay for a good and production cost, the sum of wages, and normal profit, rents by dominant position and inefficiencies are primarily safeguarded from competition by institutional and market constraints. This type of rent, also defined as absolute, differs from the differential one that arises from a restriction in the availability of land of a certain quality.

The genesis of absolute rent is, in fact, due to the general scarcity of land and to the phenomenon of artificial scarcity (accumulation of a resource in a few hands).

Moving from agricultural to urban environments, the concepts of differential and absolute rent received appropriate adjustments. In the early 1960s the Von Thünen model was considered and adapted to an urban environment by Alonso [5]. His contribution makes the model more specific for the urban environment, overcoming the assumption that only transport costs are an expression of impedance of space and preference for more central locations. In the same way, Alonso also assumes the competition between different economic activities, which spatially settled in the city depending on their availability to pay rent, as a basis of location choices and consequential value distributions. The main difference with the previous model is the influence of a new variable with respect to the choice: the size of the apartment.

Maintaining the basic assumptions already defined by Alonso, Wingo [6] developed a model that introduces the "free time" variables in family units' localization decision.

Alonso and Wingo models, based on the original idea of a concentric ring city, over the years have been refined assuming two or more independent competitive or complementary centres, with equal or different sizes.

The close relationship between position rent and transportation costs assumes a secondary role in these models; rent is mainly linked to the whole of the relationships between an element and its surrounding environment, made possible by the area. Each land parcel includes a set of spatial relations with economic and social activities taking place around it. Considering specific uses (residential, commercial, etc.), this set of relationships is reflected in many offer prices [7]. As a consequence, urban qualities (available space, amenities, sensu latu) of an area and the distance from major service centres, accessibility (in terms of time, inconvenience, and money) to the centre of the social life or work place, the proximity to markets for businesses, etc., gain value.

These are not reproducible factors, which determine comparative advantages and disadvantages of different places and segments and, therefore, a different attractiveness in buyers' opinions, a consequent different willingness to pay; in other words, a differential rent. Static analysis models applied to urban reality highlighted the organizing role played by differential rent, resulting from the different advantages offered by individual portions of a territory [8]. These models have allowed, and allow, interpretation of the effects that economic, demographic, and technological growth or modification 
of town planning regulations determine on the structure of values and urban uses [9-11]. However, these models have severe limitations in their ability of predicting or analyzing the price level of areas. Consequently, real estate value dynamics are not justified by a mere analysis of differential rent.

Urban land is one of the factors of building production whose quantity in time tends to shrink according to the construction activity itself. Reducing the amount of residual spaces, urban land rent, in its dynamic aspect, is configured just like an absolute or monopolistic rent.

The explicit consideration of the time variable in relation to the originating rent phenomenon can help in understanding some important genetic elements of the phenomenon itself. The limit of static analysis is mainly the inability to take into account the absolute rent arising from external economies or the occurrence of monopolistic conditions [12]. For example, a public operator or, also, people motivated by cumulative preference phenomena, can change scenario forecasts resulting from competitive schemes which analyse strictly economic atomistic actions [13]. Land use decisions may direct urban expansion towards certain guidelines favoring collusion between landowners [14].

In generating expectations about levels of utility or income of areas in the future, the subsequent strategies of demand and supply could especially change values over time, generating absolute rent. A vast review of the literature on land rent was carried out by Park [15].

The need to balance static analysis, which bases its foundation on the assumption of a competitive market, with the empirical evidence of monopoly rents, the idea to mix the "walled city with open city", poses some clear theoretical problems that require much more extensive analysis of a dynamic nature [16].

\section{Materials and Methods}

Urban land incorporates the effects of the rent. Therefore, a historic series of real estate values in urban areas of regional chief towns must be created for study purposes. Nevertheless, a systematic survey of average urban land values does not exist. Records by real estate observation agencies usually provide unit average surface quotations of buildings with different uses, located in different areas of urban centres.

Quotations used in the present study were inferred by "Consulente Immobiliare", a specialized magazine by Sole 24 Ore, providing the historic series since 1977. It performs measures in every town, according to three homogeneous areas: centre, semi-centre, and suburbs. The land represents only a component of the building quotation (the remaining part is the built one).

Urban land rent has its economic quantification in the difference between the market value of a property, of a building, or potentially buildable land, and the sum of the costs of the original factors. Since urban land rent is linked to location, it essentially belongs to the land and not to what is built on it.

Considering two properties, identical in all physical and technical features, realized at the same time but located in different places of a city, one in the centre and the other one in the suburbs, the possible value difference between the two properties is not due to a cost of production change, but to the different assessment of the areas on which the two buildings are located [17].

Once known real estate value series, building costs of a civil building for the same time interval (1977-2012) has been calculated in order to determine a land value series. Indices of building cost variation by the National Institute for Statistics (ISTAT) have been used. Land-to-building ratio (LBR) is another parameter used to generate value dynamics in urban areas. It refers to the ratio between the market values of free land and building to realize on it (the product of building transformation). Such a parameter has been systematically recorded by Sole 24 Ore (the main Italian business and financial newspaper) for the considered time span, with regard of the three different town areas (centre, semi-centre, suburbs).

The LBR survey made by Sole 24 Ore for the three investigated areas within the Italian regional capital cities shows not significant oscillations during the reference interval. This would mean that, over time, property and land values grew at the same rate. Since property value is equal to the sum of land value and building cost (including the entrepreneur's profit), also the latter would have to grow 
at the same rate. However, the recorded dynamics of property values and building costs (excluding profit) show apparent differences. As an example we include charts of Figures 1 and 2 relative to the city of Naples.

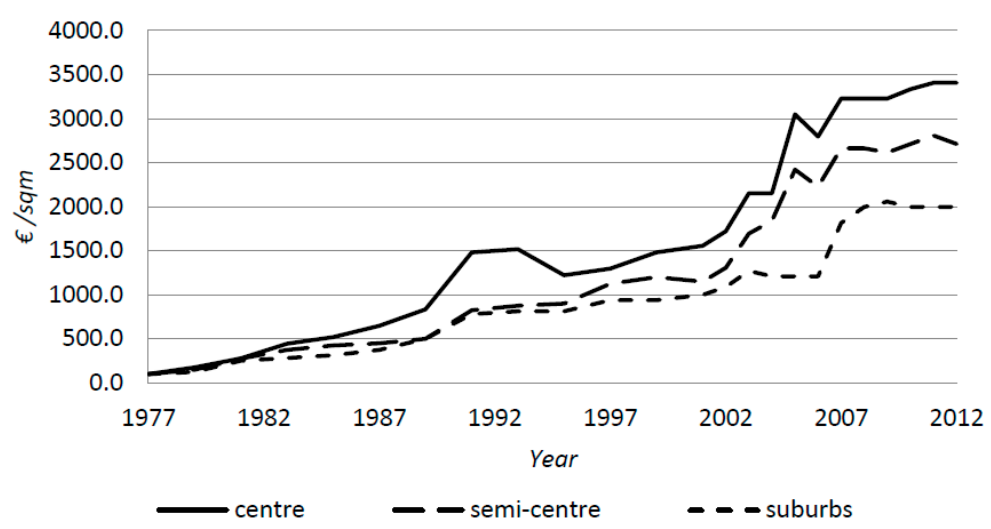

Figure 1. Trend in property values in Naples from 1977 to 2012 for different urban areas.

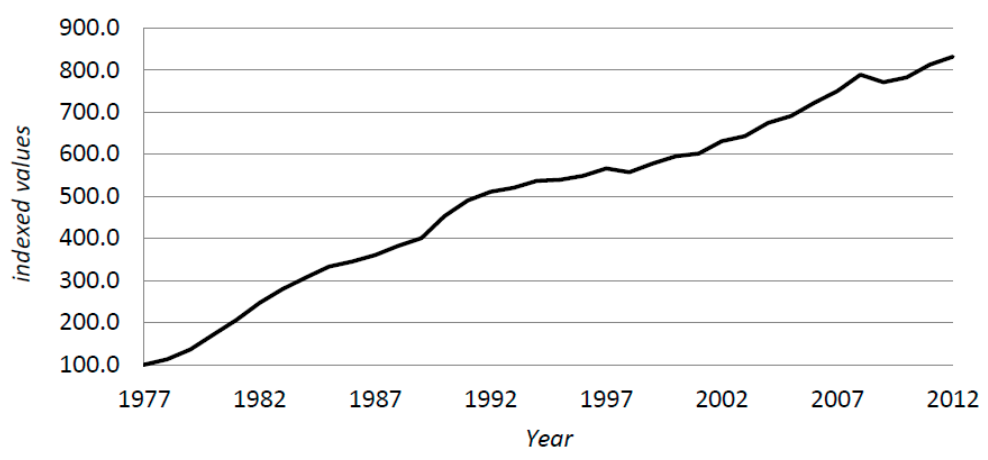

Figure 2. Trend in building cost in Naples from 1977 to 2012.

The assumption that LBR is constant implies, therefore, a change in entrepreneur's profit. So if property value grows at a rate higher than building cost, it is conceivable that the profit grows at a rate higher than property value.

It should be specified that the cost of production does not contain entrepreneur profit in building transformation which is, therefore, part of the land value [18]. There is a close relationship between extra profit and rent. The first is one of the factors that determine city dynamics: new production activities are attracted, in particular, to urban areas by the presence of extra profits. This determines, after a certain time interval, a new equilibrium condition with the transfer of extra profit (tending to zero) from the production to the landowners in the form of rent.

Following such considerations (even assuming LBR ratio constant), the following formula was elaborated to measure land rent variation as a function of the change in real estate values and building cost (net of profit). It is assumed that each annual figure is the expression of an equilibrium condition, and that, in the observation of value dynamics, the subsequent equilibrium condition (to be identified as a consequence of a new phenomenon generator of rent or its evolution) is immediately realized. This means that extra profit is always absorbed in rent. Finally, knowing the value of an area at year $n$, the evolution of rent at year $n+1$ is measured as the difference between the value increase (or decrease) of a new building and the corresponding variation of building costs.

$B v_{n}$ Average real estate value index referred to year $n ; C c_{n}$ Building cost index for a residential building referred to year $n ; L v_{n}$ Urban land value index referred to year $n ; \Delta B v_{n}$ Real estate variation (Building value); $\Delta C c_{n}$ Building cost variation; $\Delta L v_{n}$ land values variation (urban land rent); $\mathrm{LBR}=\mathrm{Lv} / \mathrm{Bv} ;(1-\mathrm{LBR})=1-\mathrm{Lv} / \mathrm{Bv}=(\mathrm{Bv}-\mathrm{Lv}) / \mathrm{Bv}=\mathrm{Cc} / \mathrm{Bv}$. 


$$
\begin{gathered}
\Delta B v_{n}=\frac{B v_{n}-B v_{n-1}}{B v_{n-1}}=\frac{B v_{n}}{B v_{n-1}}-1 \\
\Delta C c_{n}=\frac{C c_{n}-C c_{n-1}}{C c_{n-1}}=\frac{C c_{n}}{C c_{n-1}}-1 \\
\Delta L v_{n}=\frac{L v_{n}-L v_{n}}{L v_{n-1}} \\
L v_{n-1}=B v_{n-1}-C c_{n-1}=L B R \cdot B v_{n-1} \\
L v_{n}=B v_{n}-C c_{n}=\left(1+\Delta B v_{n}\right) \cdot B v_{n-1}-\left(1+\Delta C c_{n}\right) \cdot C c_{n-1} \\
\Delta v_{n}=L v_{n}-L v_{n-1}=\frac{\left(1+\Delta B v_{n}\right) \cdot B v_{n-1}-\left(1+\Delta C c_{n}\right) \Delta C c_{n-1}-L B R \cdot B v_{n-1}}{L B R \cdot B v_{n-1}} \\
=\frac{\left(1+\Delta B v_{n}\right)-(1-L B R)\left(1+\Delta C c_{n}\right)-L B R}{L B R}=\frac{\Delta B v_{n}-(1-L B R) \Delta C c_{n}}{L B R}
\end{gathered}
$$

In the following paragraphs, we present the procedure used to build the time series of land value variation. We considered the variation of each parameter measured since the reference year (e.g., 1977) to which we assigned a value of 100 , rather than its absolute values to analyse the series dynamics.

\section{Data}

Residential use has been considered as a reference, considering that real estate values relative to housing reflect on other segments and better summarize the generality of the housing market. Time series of average real estate prices of housing by area (centre, semi-centre, suburbs) of regional capital cities have been extracted from the 2012 real estate yearbook of Sole 24 Ore. These average prices refer to new constructions by period of reference. The value of surface area cost per square meter was deducted from the Italian Ministerial Decree for subsidized loan transactions (Decreto Ministeriale n. 9816 of 3 October 1975). This cost was estimated according to location (Northern, Central and Southern Italy and islands), population size of the town, and other typological characteristics.

Values at 1975 have been adapted for 2012, using the "index of construction cost of residential building changes", defined by the Italian National Institute of Statistics (ISTAT). Although these indices are measured and differentiated by region, all values have been converted from nominal into real ones, measured considering the inflation. The Table 1 below reports, as an example, data of the Municipality of Ancona.

Table 1. An example of data in the Municipality of Ancona.

\begin{tabular}{cccc}
\hline Year & Centre & Semi-Centre & Suburbs \\
\hline 1989 & 100 & 100 & 100 \\
1990 & 108 & 105 & 78 \\
1991 & 122 & 125 & 108 \\
1992 & 114 & 101 & 70 \\
1993 & 109 & 84 & 49 \\
1994 & 131 & 118 & 161 \\
1995 & 149 & 149 & 265 \\
1996 & 157 & 170 & 268 \\
1997 & 168 & 193 & 274 \\
1998 & 166 & 193 & 346 \\
1999 & 162 & 187 & 400 \\
2000 & 163 & 175 & 367 \\
2001 & 164 & 166 & 344 \\
2002 & 209 & 233 & 526 \\
2003 & 219 & 239 & 609 \\
\hline
\end{tabular}


Table 1. Cont.

\begin{tabular}{cccc}
\hline Year & Centre & Semi-Centre & Suburbs \\
\hline 2004 & 239 & 243 & 567 \\
2005 & 241 & 289 & 655 \\
2006 & 234 & 297 & 739 \\
2007 & 227 & 304 & 709 \\
2008 & 216 & 287 & 664 \\
2009 & 247 & 314 & 800 \\
2010 & 250 & 307 & 779 \\
2011 & 248 & 307 & 735 \\
2012 & 230 & 278 & 700 \\
\hline
\end{tabular}

Figures A1 and A2 in Appendix A will provide a graphical representation of these data. More particularly, Figure A1 describes the trend in land values for urban territories of cities, in terms of absolute value, with a base price index at 1977 (left) and the same trend (right) indexed (index 100 at 1977). In Figure A2, in order to better highlight the real estate dynamics of the last two cycles, the dynamics of indexed values from 1988 to 2012 are portrayed.

\section{Empirical Analysis of Results}

\subsection{General Considerations}

During the phase of urban expansion in Italy, ranging from post-war reconstruction until the 1970s, the manifestation of absolute rent produced by the gradual expansion of building fabrics was evident. Public decisions to move built boundaries valorised marginal lands, removing them from agricultural use.

On the other hand, an increased economic welfare and a rapid progress in the field of transport reduced disutility of distance, in terms of costs and physical and moral inconvenience, flattening curves of differential rent. Congestion of central areas emphasized this phenomenon, producing a price increase in peripheral zones.

With the tertiary revolution of the 1980s, the interests changed again within cities, in order to meet the needs of localization and prestige of new urban functions, using properties available from the disposal of industry and public functions (army barracks, railways, post offices, government offices, etc.). In those years the differential rent prevailed, not generated by land use change (from agricultural to buildable), but produced by positional advantages.

The transformation became much more complex and not very decipherable in terms of both actors and the modality. To end this phase, the explosion of the "housing bubble" in the early 1990s intervened. At the end of this decade a new cycle of real estate development started with growth levels never reached before $[19,20]$. This cycle has produced a very large increase at the beginning and, later, a rapid decline of a type of so-called pure rent. Pure rent can be considered as a condition of the absolute rent evolved; it potentially concerns all existing property. It is the product of the process of real estate market financialization, developed by the spread of funds, the main vehicle of real estate investment in monetary form, and the securitization of many real estate assets.

Real estate assets have been transformed in securities, which have been artificially emphasized by using unscrupulous credit policies that, stimulating families and small entrepreneurs to debt, have promoted a strong growth in property purchase demand. In this way a general real estate euphoria has spread, which determined an unjustified valorization.

Rent rising produced debt transfer from companies to households, producing a significant advantage for the credit system that has organized and managed financialization. This activity has also detracted important resources to real productive activity, redirected for the benefit of speculative actions [21]. The subsequent crackdown of family budgets (lower income) and growth rate caused the system collapse due to insolvency. 
Analyzing the results, it is possible to observe that rent curves fluctuate with a similar trend of real estate prices, but with much more amplified fluctuations.

We have already argued about post-war reconstruction that generated absolute rent, which affected, until the 1970s, marginal areas of cities, changing and expanding urban area boundaries.

The lack of programming activity, and the subsequent urban planning choices without a strategy, or sometimes limited at speculative purposes, transformed extensive agricultural areas into development zones. Failures produced by that season are still evident today.

Our observation begins in 1977. The dynamics of rent are represented starting from the tertiary sector revolution (late-1970s and early-1980s), that changed the direction of city transformation. A centripetal force was added and partly replaced a centrifugal force. Until the 1970s demography was the main generative factor in real estate demand. In the post-industrial period development of tertiary functions, the changing needs of individuals, different compositions of households, and higher incomes produced a demand for an improvement in housing choice [22].

Society became much more complex with more complex behaviors. The tertiary sector, driven by the quality in activity location choice, found a solution in the reuse of central decommissioned properties. Regarding housing demand, this period is characterized by a return towards historical centres for particular social groups, such as singles or practitioners [23,24], while, on the contrary, other groups, such as parents with young children or elderly people, preferred to choose more external areas, which are greener and have better environmental quality.

The mutation of demand oriented to capture positional advantages generated, in the first observed decade, an evident differential rent, finding the loss of large shares of accumulated rent in suburbs compared to central and semi-central zones. This is very evident especially in large cities, such as Palermo, Milan, Rome (Figure 3), Turin, and Bologna, but also in smaller cities, such as Cagliari, L'Aquila, Perugia, Potenza, Trento and Trieste.

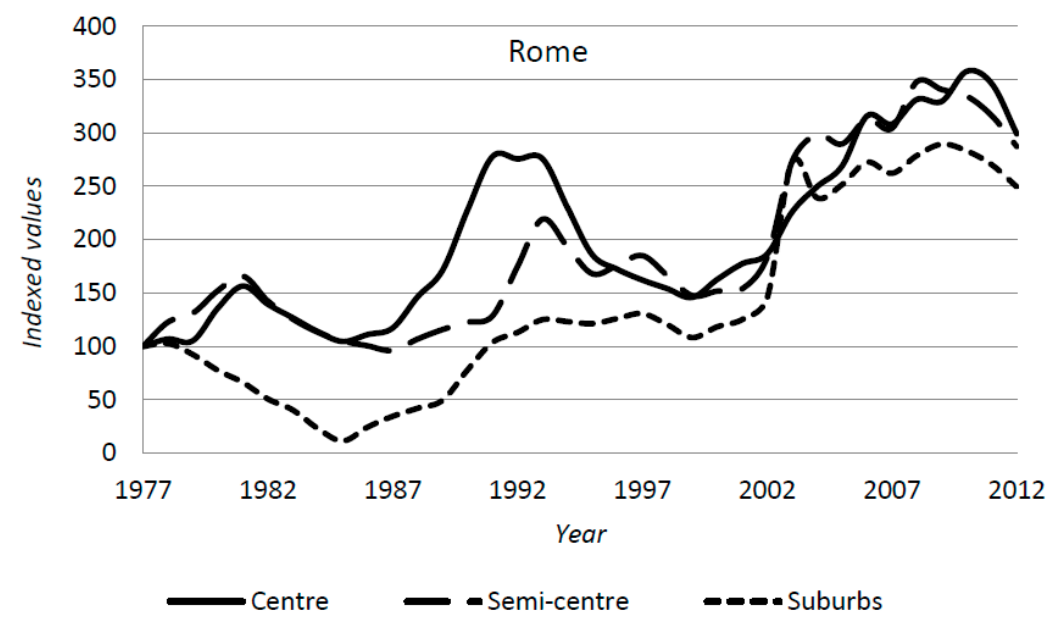

Figure 3. Trend of urban land values from 1977 to 2012 in Rome.

Starting from the 1990s, although the dynamic of rents no longer seems so homogeneous in regional Italian capital cities, from a general observation of graphs it is possible to notice a different trend of rent, with more pronounced fluctuations and a trend more and more disengaged from the actual economic values.

Most of the series of land values, recorded in the last 20 years in Italian cities, show the succession of two real estate cycles, one with a peak between 1991 and 1993 and one with a peak between 2006 and 2008.

The dynamics in both cases reflect the rise and decline of absolute rent, the so-called pure rent, i.e., the rent produced by the real estate market financing that occurs in almost the entire urban fabric, lessening the importance of locational factors [25-28]. 
The phenomenon is evident in cities such as Bari, Bologna, Florence (Figure 4), and Milan, where the dynamics of the values in the three zones (centre, semi-centre, suburbs) are nearly coincident in relative terms.

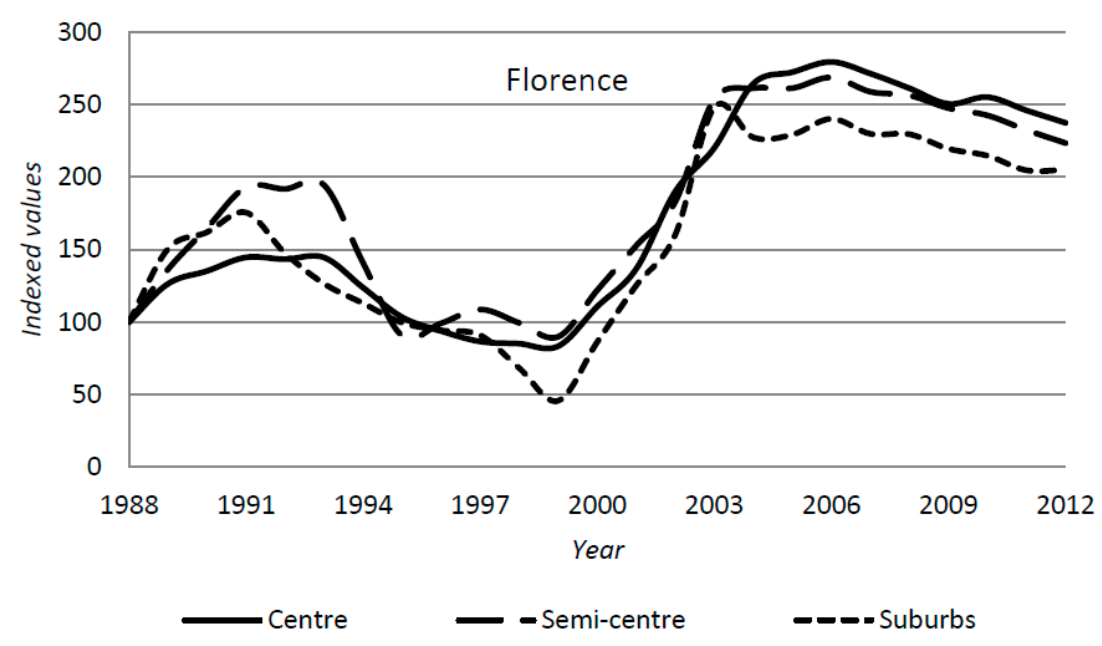

Figure 4. Trend of indexed urban land values from 1988 to 2012 in Florence.

From the observation of quantitative oscillations, it is also clear that while the rise in major cities' rents during the two cycles is comparable, in other cities (minor ones) these fluctuations have different proportions. In smaller cities the first cycle is much less pronounced in the quantitative dimension compared to the second. This is probably due to the entrance of finance in the real estate market, even if special laws still do not regulate it. During the 1980s industrial groups, insurance, and banking services provided a recapitalization through the externalization of their large real estate properties with greater impact in the cities where their availability was larger.

In smaller cities, instead, the dynamics of values reflect an ownership structure that records much higher percentages in the availability of households and a consequent lower level of debt.

In subsequent years, the pervasive growth of information technology has contributed to the globalization of markets, including the real estate market. This phenomenon led to more homogeneous dynamics within the same country (between small and large cities) and beyond national borders, among the largest developed countries.

During the rise of prices between 1999 and 2006, the globalization of information helped to sustain demand as market euphoria spread like an infection [29].

The two real estate cycles also differ in the phase of declining values. While in the first cycle, the fall of prices after the bubble of 1992 was sudden, in Italy after 2006, in contrast to what happened in other Western countries, a similar variation in property values did not correspond to a sharp reduction in transactions. This is justified, once again, by the particular structure of the Italian real estate market whose stock, especially in the residential sector (which certainly drives the market), is mainly based on household availability (approximately $92 \%$ ).

Households use property as a principal residence; $64.4 \%$ of the stock either leased (8.9\%), at no charge (2.8\%), or held as a second home (16\%) [30]. The largest share of Italian households' savings, always in growth even in periods of capital falling gains, is normally directed to house purchases. This helped to grow, over time, the rate of net household wealth due to housing; about $53 \%$ of the total in 2011 [31]. This particular tendency of Italian households towards the house and the prudence of Italian banking system that has accumulated on their balance limited quantities of securities linked to subprime mortgages, have made the Italian property market less exposed to the explosion of the housing bubble generated by junk bonds [32]. 


\subsection{Local Aspects and Peculiarities}

Information concerning single town infrastructures were not considered in the performed analysis. This element has relevant effects on the analyzed phenomena. Therefore, the analysis is too general and the scale is too wide to highlight the strict relationship between position revenue and public transport investments, well documented in the literature [33-36]. We consider here the revenue dynamics, and provide their interpretation, by imagining an interaction between trade-off and filtering down forces.

Location choice and real estate geography values are determined by supply and demand. The trade-off mechanism interprets households' location choice and, therefore, the demand for housing as a condition of equilibrium between housing and mobility cost. This cost should be understood in terms of the transport service cost and the opportunity cost of transferring time spent.

The analyzed cities can be classified, according to the observed rent dynamics, into several categories. The cities of Ancona, L'Aquila, Naples, Perugia, Reggio Calabria, Rome, Turin, Trento, and Venice belong to the first category, the largest one. In these cases, an emerging of a differential rent between suburbs and the rest of the city is evident, especially in the last 20 years.

This trend can be explained by the phenomenon of urban sprawl. The term urban sprawl is related to the process of urban expansion with a dispersive and diffusive nature which, in the case of the mentioned cities, exceeds both boundaries of the historic centre and the crown surrounding the centre, completely saturating at the end of the 1980s [37,38]. The phenomenon also involves semi-central areas of Milan and Trieste, but it is more evident in the cities of Bari, Cagliari, Campobasso, Naples, and Genoa. In this group, the rent gap between peripheral and semi-central areas remains substantially unchanged over time, while only the central area tends to lose location advantages.

In the competition between various economic actors to access the central areas of a city, the most vulnerable actors are, precisely, families that direct their choice towards suburbs. These economic factors encourage the urban sprawl phenomenon, which spreads urban areas over hinterlands, thus creating a galaxy of scattered settlements around the consolidated city $[39,40]$. The trend toward the external part of city centres for some cities also derives from a filtering down phenomenon.

This model assumes that the wealthiest families are moving towards newer neighborhoods, built on the edge of the city, characterized by better construction and environmental quality than parts located in the city centre or semi-centre. These are made available for the location of families with incomes gradually decreasing towards the centre, where buildings are more and more obsolete and cheaper.

For some cities, the filtering down process has been completed as described in the literature: obsolete residential neighborhoods have been demolished to make space for directional centres. In other cities, or in some neighborhoods of the same city, this has not happened. The reason is based on the difference between American and European city models and, more specifically, for the Italian model.

In Italian historical centre conversions are not possible, due to regulatory physical functional restrictions.

When urban renewal projects are not provided, social gaps occur with population replacement or social segregation phenomena. These elements have led, in some cases, to a reduction of the values of central areas, (e.g., Bari, Cagliari, and Genoa). Palermo, finally, is a special case. Graphs show that, in the last twenty years, the differential rent has favored semi-central areas without affecting suburbs. The presence of degraded and socially-marginalized neighborhoods in the suburbs of the city paralyzed rent in these areas.

Location choices have been directed towards semi-central areas, where the differential rent exploded, prevailing on that pure rent whose effects were evident and confined only in the central area of the city.

\section{Conclusions}

This paper attempted to interpret the results of an empirical analysis conducted on land value changes in Italian regional capital cities according to urban land rent theories. 
The analysis of urban land rent evolution and the comparative study of the phenomenon compared to urban geography (centre, semi-centre, and suburbs) highlighted the difference among the various urban systems investigated. This difference is essentially explained by the different weight of macroeconomic variables, related to national and international contexts, and microeconomic variables, closely related to local demand and supply, in the process of rent formation.

The results showed a difference between minor and major towns, independently of their geographic location. Such a difference is probably due to a different ownership structure of urban real estate, with industrial, insurance, and bank groups in major centers, often using their assets as true financial tools. In some cases urban development and social dynamics produced a differential rent towards central areas of cities (Palermo, Milano, Roma, Torino e Bologna, Cagliari, L'Aquila, Perugia, Potenza, Trento, Trieste); in other cases rent growth involved peripheral and semi-central areas (Ancona, L'Aquila, Napoli, Perugia, Reggio Calabria, Roma, Torino, Trento and Venezia). It is, therefore, essential to justify the different dynamics, even the sprawl phenomenon, where it is more pronounced, that have made the differential rent more evident.

The rent may be considered as the overlap of changes in urban land values produced by location choices and external economies. Location choices can be interpreted according to trade off theory.

Land values are, therefore, the result of a partial equilibrium between the economic value of centrality and the cost of mobility, but also between the cost of mobility and the advantages of proximity to reciprocal, the potential of social interaction, the value of environmental quality or, simply, the image.

The observation of empirical data showed that urban land rent, in part, and in some cases, significantly, reflects the dynamics of the transformation of a city and market competitiveness of different areas of a city, as an expression of the change in time equilibrium. Where the dynamic of values finds its justification in the prevailing pure rent, it is evident that the urban and social structure of the city is in a state of stable equilibrium.

The presented study highlights criticalities generated by the processes of transformation that have affected some Italian urban contexts. The speed of urban transformation and the consequent growth of differential rents between different urban areas, when it is not accompanied by a good and balanced planning activity, can produce inequity and social inequality.

The analysis and regulation of urban transformation [41-43], that also allows obtaining the funds through taxation of the capital base reflecting actual real estate values, can ensure sustainable development and the quality of life for citizens.

Author Contributions: All authors contributed equally to this work. In particular, experiment design, and writing of the manuscript was developed jointly by all authors.

Conflicts of Interest: The authors declare there is no conflict of interest. 
Appendix A

Centre

Ancona

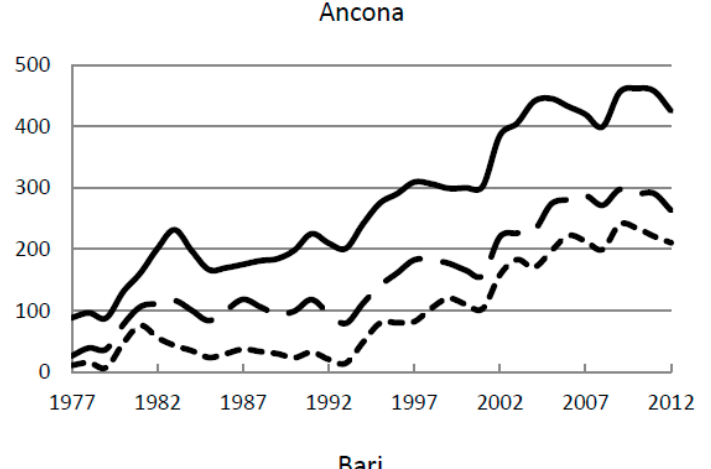

Bari
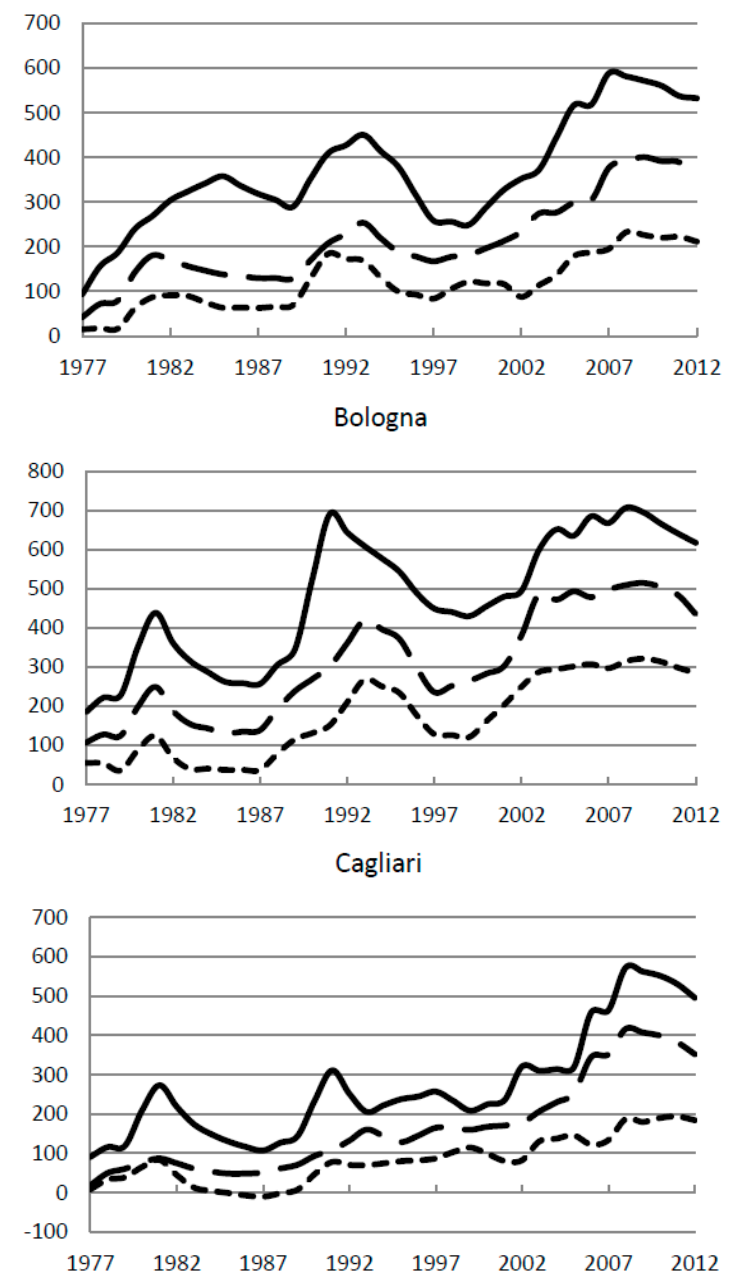

- Semi-centre

- - Suburbs

Indexed values

Ancona
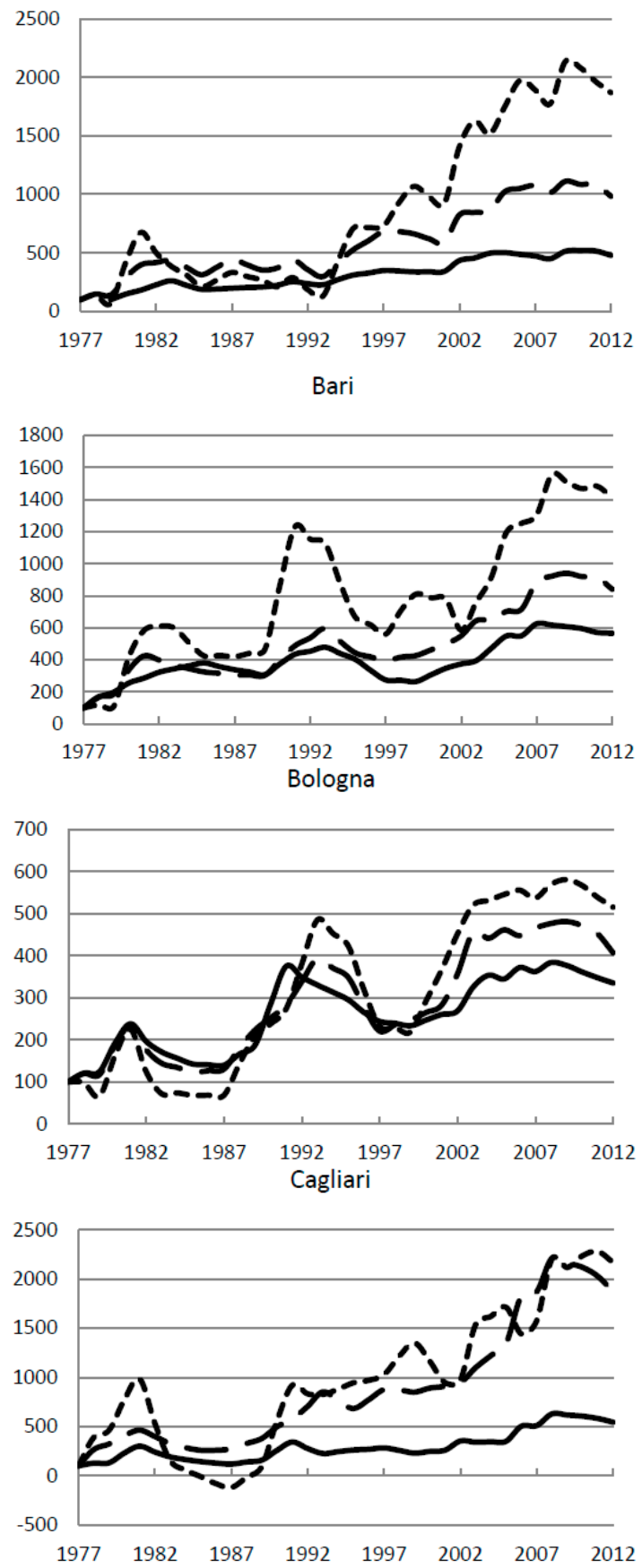

Figure A1. Cont. 
Campobasso
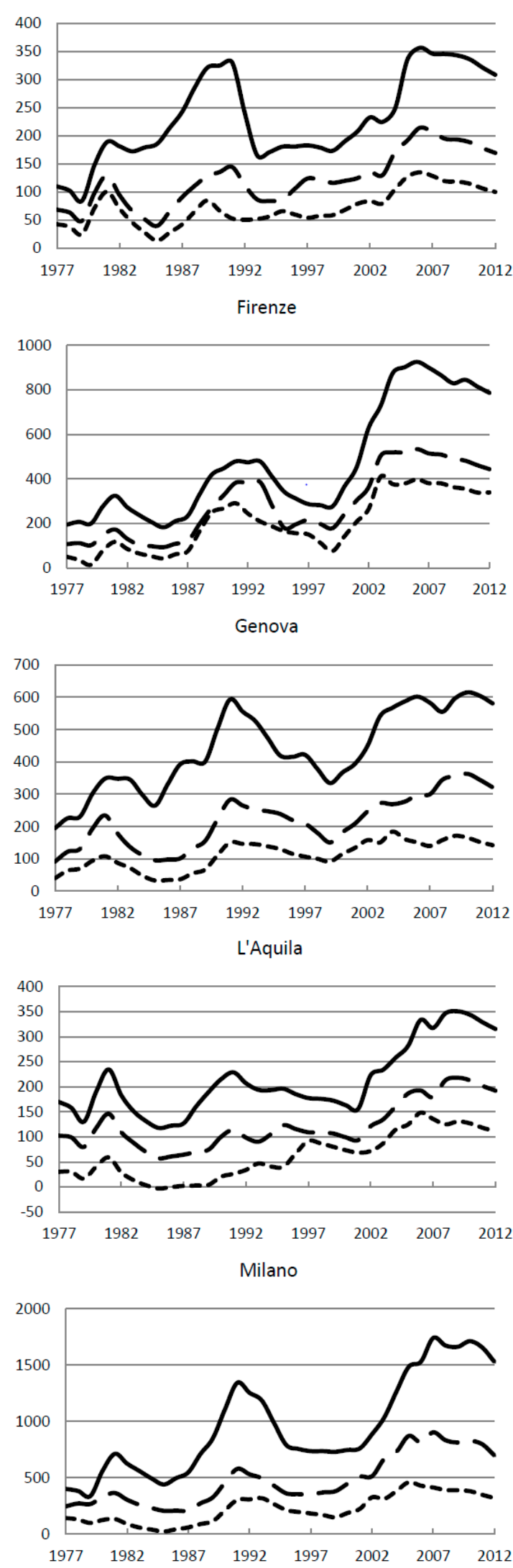

Campobasso
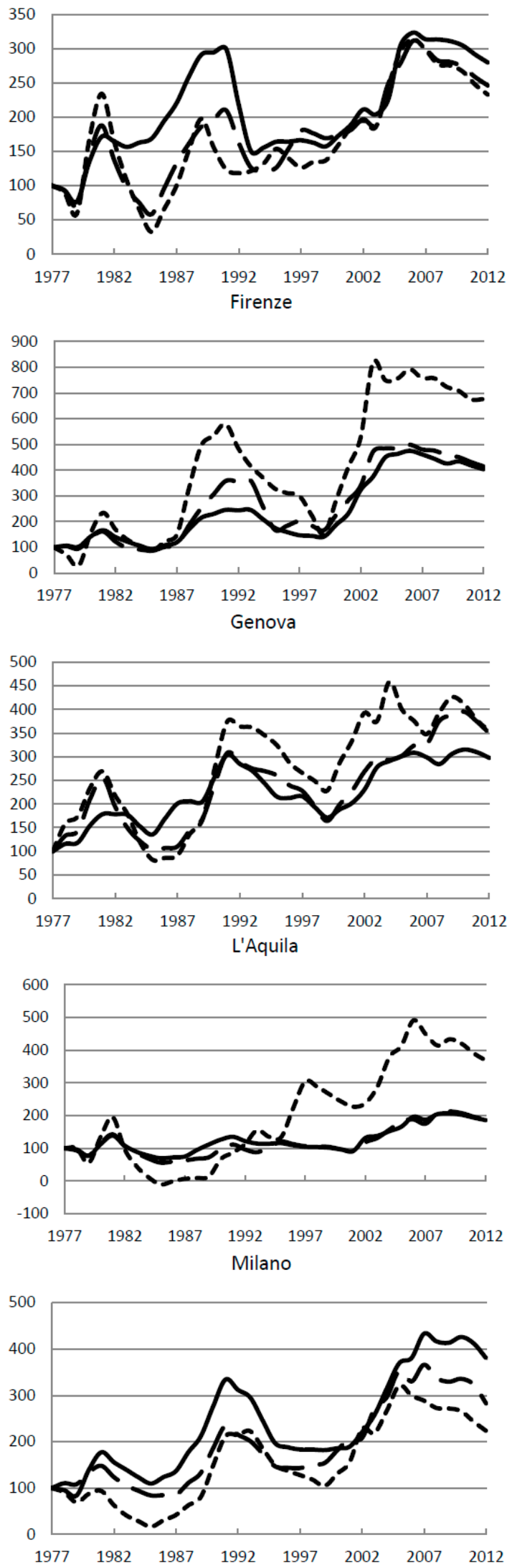

Figure A1. Cont. 
Napoli
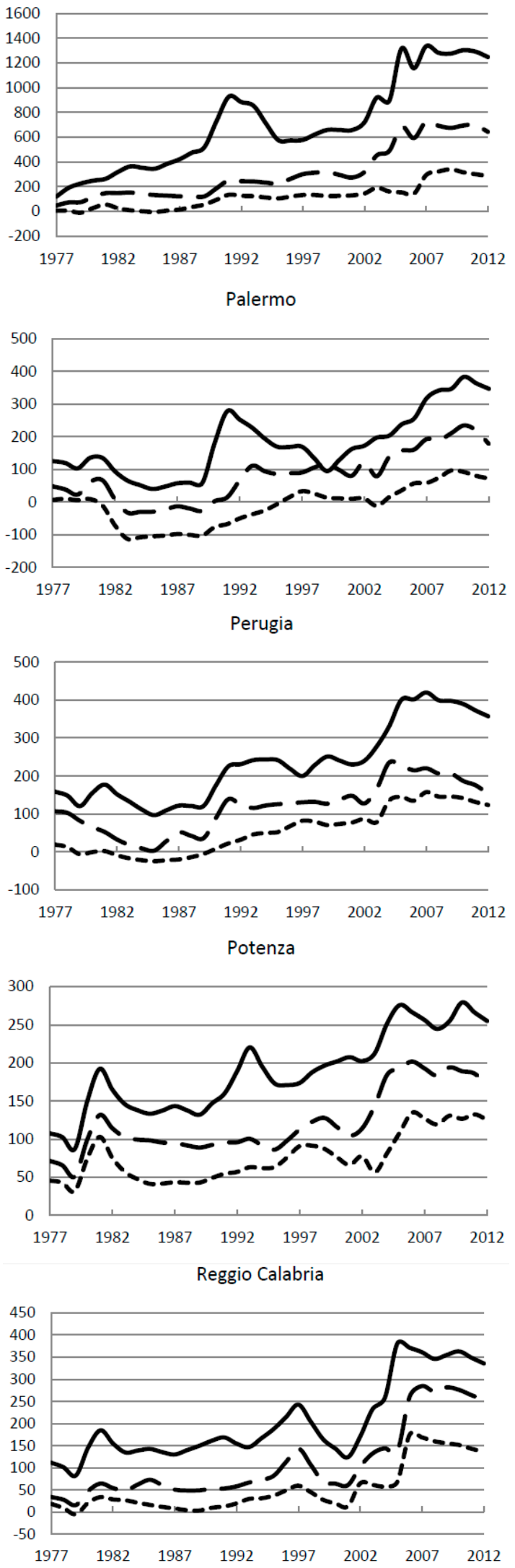

Napoli
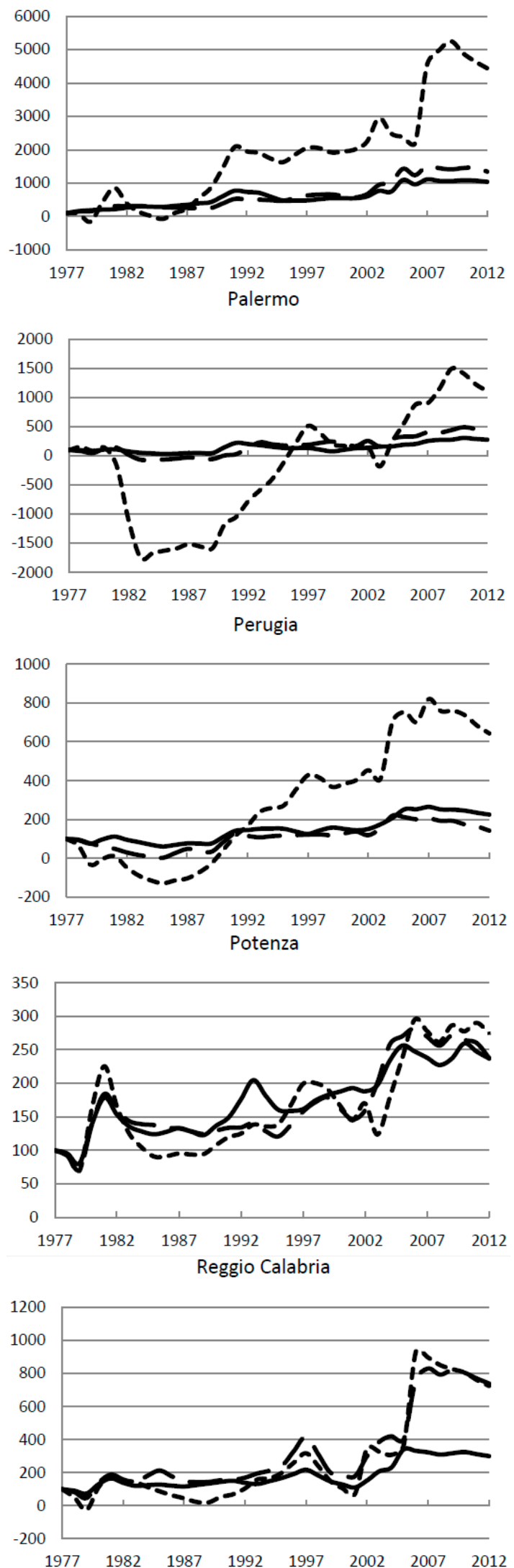

Figure A1. Cont. 
Roma
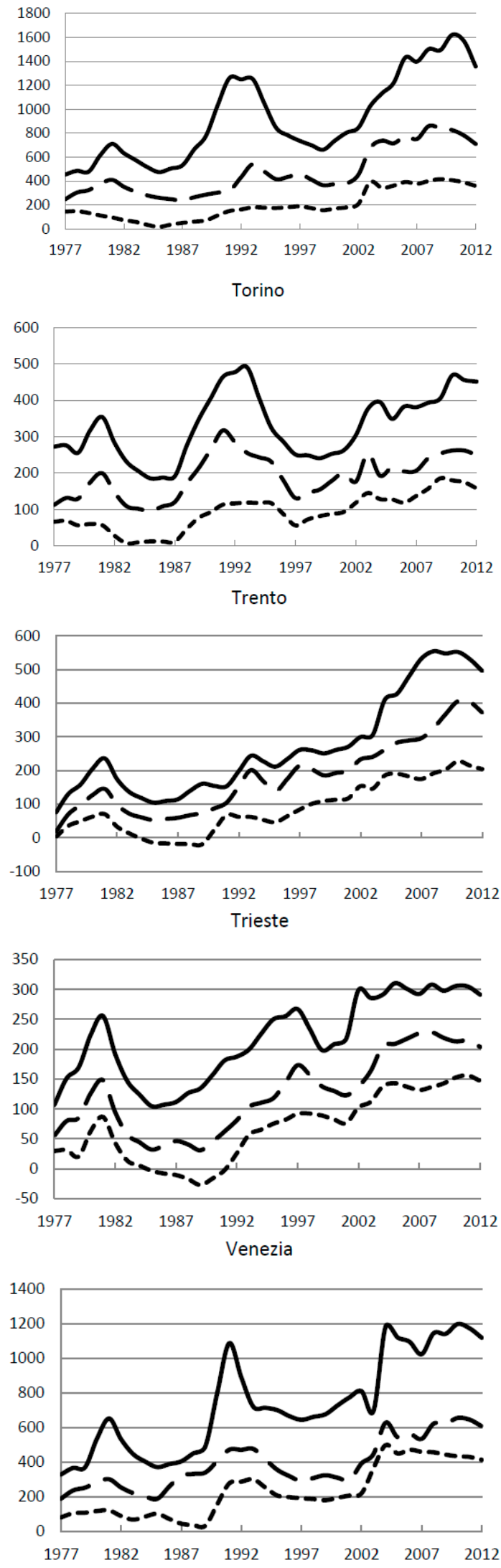

Roma
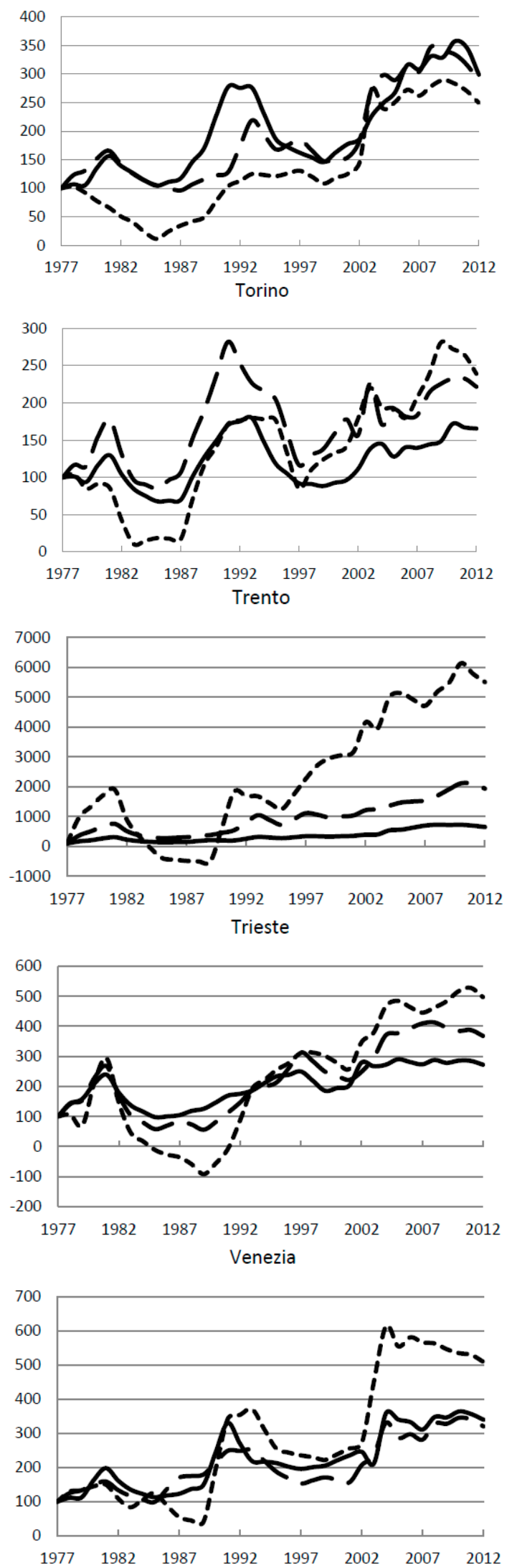

Figure A1. The trend of values of urban land from 1977 to 2012 in the regional Italian capital cities and for different urban areas. 

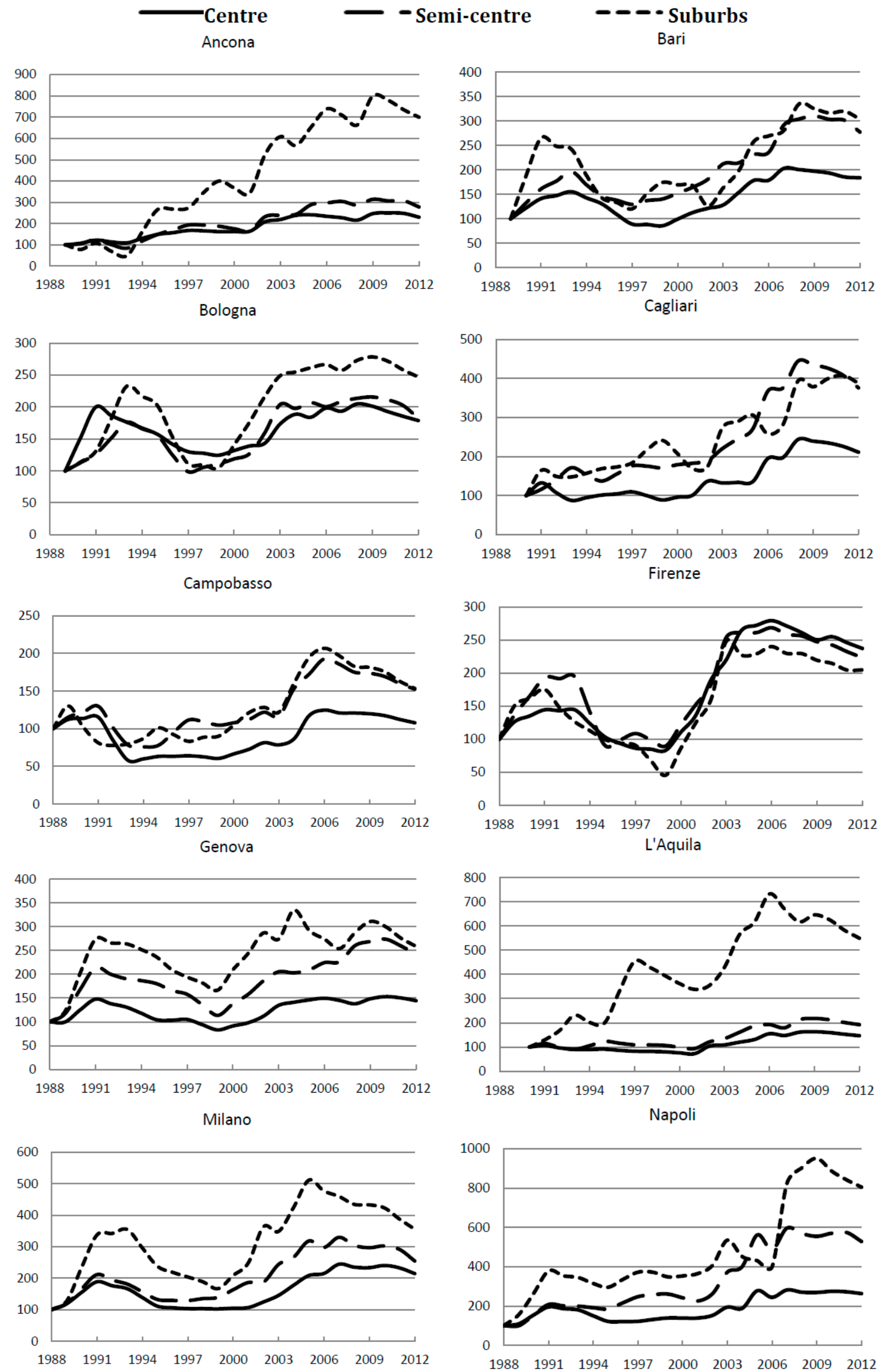

Figure A2. Cont. 
Palermo

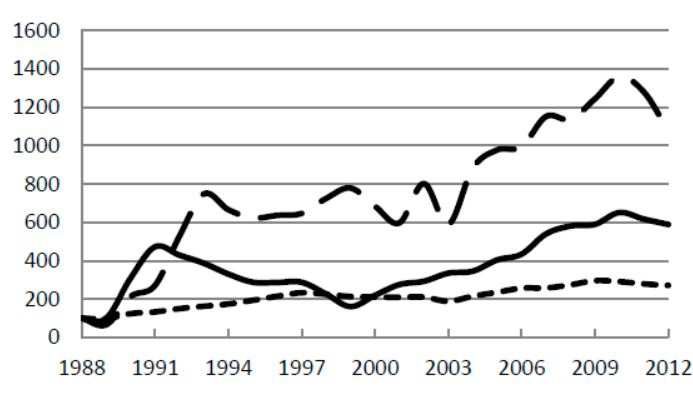

Potenza
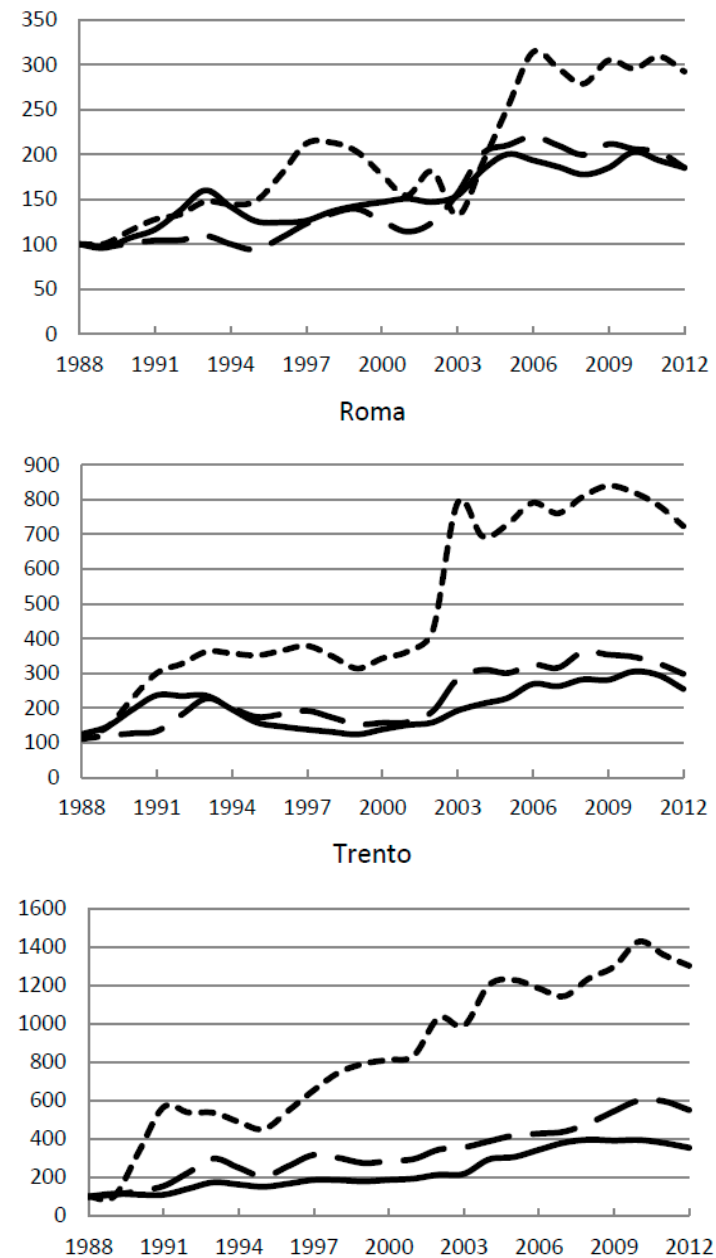

Venezia

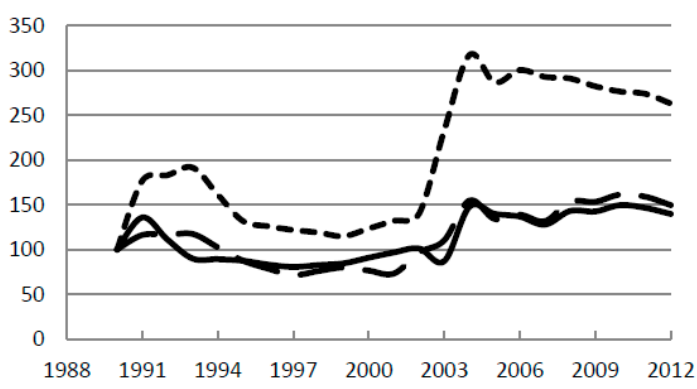

Perugia
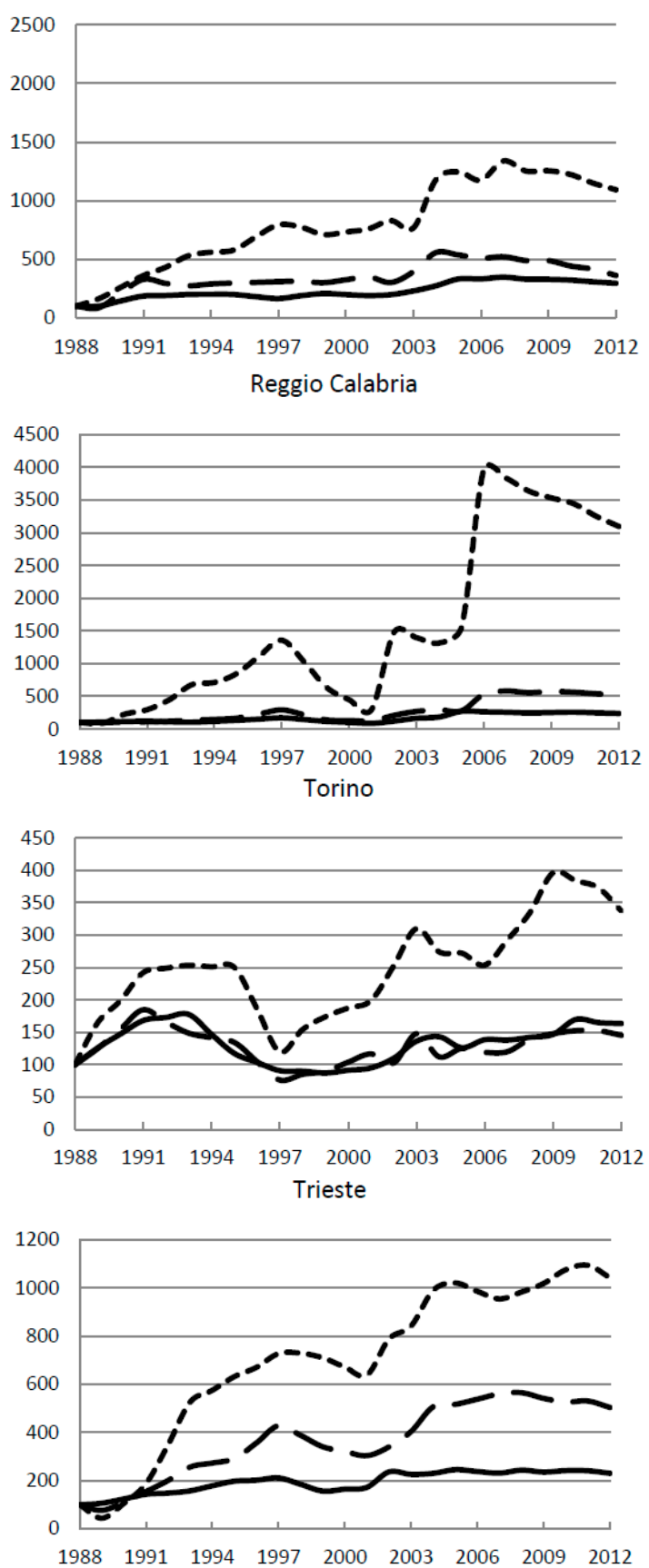

Figure A2. The trend of indexed values of urban land from 1988 to 2012 in the regional Italian capital cities and for different urban areas. 


\section{References}

1. Smith, A. An Inquiry into the Nature and Causes of the Wealth of Nations; Methuen \& Co., Ltd.: London, UK, 1776.

2. Ricardo, D.; Gonner, E.C.K. The Principles of Political Economy and Taxation; World Scientific: Singapore, 1819.

3. Von Thünen, J.H. Der Isolierte Staat in Beziehung auf Landwirtschaft und Nationalökonomie, oder Untersuchungen über den Einfluß, den die Getreidepreise, der Reichthum des Bodens und die Abgaben auf den Ackerbau ausüben; Perthes: Hamburg, Germany, 1826.

4. Fratini, S.M. La Rendita Assoluta di Marx e le Equazioni di Prezzo di SRAFFA; Collana del Dipartimento di Economia-Università degli Studi Roma Tre: Rome, Italy, 2009.

5. Alonso, W. Location and Land Use: Towards a General Theory of Land Rent; Harvard University Press: Cambridge, MA, USA, 1964.

6. Wingo Jr, L. Transportation and Urban Land; Resources for the Future: Washington, DC, USA, 1961.

7. Qina, Y.; Zhub, H.; Zhud, R. Changes in the distribution of land prices in urban China during 2007-2012. Reg. Sci. Urban Econ. 2016, 57, 77-90. [CrossRef]

8. Coloia, A. Rendita di Posizione e Utilizzazione del Suolo Urbano. Riv. Int. Sci. Soc. Ser. III 1967, 38, $219-231$.

9. Solow, R.M. A Contribution to the Theory of Economic Growth. Q. J. Econ. 1956, 70, 65-94. [CrossRef]

10. Mills, E.S. An aggregative model of resource allocation in a metropolitan area. Am. Econ. Rev. 1967, 57, 197-210.

11. Fujita, M. Urban Economic Theory: Land Use and City Size; Cambridge University Press: Cambridge, UK, 1989.

12. Camagni, R. Economia Urbana: Principi e Modelli Teorici; La Nuova Italia Scientifica: Roma, Italy, 1992.

13. Harvey, D.; Chatterjee, L. Absolute Rent and the Structuring of Space by Governmental and Financial Institutions. Antipode 1974, 6, 22-36. [CrossRef]

14. Walker, R.A. Urban Ground Rent: Building a New Conceptual Framework. Antipode 1974, 6, 51-58. [CrossRef]

15. Park, J. Land Rent Theory Revisited. Sci. Soc. 2014, 78, 88-109. [CrossRef]

16. Magnani, I. Città. L'intreccio pubblico-privato nella formazione dell'ordine sociale spontaneo. Sci. Reg. 2006, 5, 117-127.

17. Kuminoff, N.V.; Pope, J.C. The Value of Residential Land and Structures during the Great Housing Boom and Bust. Land Econ. 2013, 89, 1-29. [CrossRef]

18. Manganelli, B. Maintenance, building depreciation and land rent. Appl. Mech. Mater. 2013, 357, $2207-2214$. [CrossRef]

19. Tocci, W. L'insostenibile Ascesa Della Rendita Urbana. Democrazia e Diritto 2009, 17-59. [CrossRef]

20. Cremaschi, M. Rendita fondiaria e sviluppo urbano nella riqualificazione urbana: Per un'ipotesi interpretativa. In Proceedings of the atti del XXIV Convegno della Società Italiana di Scienza Politica, Venezia, Italy, 16-18 September 2010.

21. Sapelli, G. La Crisi Economica Mondiale; Bollati Boringhieri: Torino, Italy, 2008; pp. 9-17.

22. Rosenthal, S.S.; Helsley, R.W. Redevelopment and the Urban Land Price Gradient. J. Urban Econ. 1994, 35, 182-200. [CrossRef]

23. McKinnish, T.; Walsh, R.; White, T.K. Who Gentrifies Low-Income Neighborhoods? J. Urban Econ. 2010, 67, 180-193. [CrossRef] [PubMed]

24. Liu, C.; O'Sullivan, D. An abstract model of gentrification as a spatially contagious succession process. Comput. Environ. Urban Syst. 2016, 59, 1-10. [CrossRef]

25. Wang, S.; Yang, Z.; Liu, H. Impact of urban economic openness on real estate prices: Evidence from thirty-five cities in China. China Econ. Rev. 2011, 22, 42-54. [CrossRef]

26. Deo Bardhan, A.; Edelstein, R.H.; Leung, C. A note on globalization and urban residential rents. J. Urban Econ. 2004, 56, 505-513. [CrossRef]

27. Parés-Ramos, I.K.; Álvarez-Berríos, N.L.; Mitchell Aide, T. Mapping Urbanization Dynamics in Major Cities of Colombia, Ecuador, Perú, and Bolivia Using Night-Time Satellite Imagery. Land 2013, 2, 37-59. [CrossRef]

28. Garza, N. The spatial and long term evolution of land prices in a Latin American metropolis: The case of Bogotá, Colombia. Rev. Econ. Caribe 2016, 18, 11-35.

29. Shiller, R.J. Understanding Recent Trends in House Prices and Home Ownership, National Bureau of Economic Research Working Paper Series, 13553. 2007. Available online: https:/ /www.kansascityfed.org/ publicat/sympos/2007/pdf/shiller_0415.pdf (accessed on 15 April 2017). 
30. Dipartimento delle Finanze e Agenzia del Territorio. Gli immobili in Italia 2012. Available online: http:/ / www.agenziaentrate.gov.it/wps/content/Nsilib/Nsi/Agenzia/Agenzia+comunica/Prodotti+ editoriali/Pubblicazioni+cartografia_catasto_mercato_immobiliare/Immobili+in+Italia/Gli+immobili+ in+Italia+2012/ (accessed on 15 April 2017).

31. Bank of Italy. Supplementi al Bollettino Statistico—La Ricchezza Delle Famiglie Italiane; Banca d'Italia: Rome, Italy, 2012; n. 65.

32. Manganelli, B.; Morano, P.; Tajani, F. House Prices and Rents. The Italian Experience. WSEAS Trans. Bus. Econ. 2014, 11, 219-226.

33. So, H.; Tse, R.; Ganesan, S. Estimating the influence of transport on house prices: Evidence from Hong Kong. J. Prop. Valuat. Invest. 1997, 15, 40-47. [CrossRef]

34. Henneberry, J. Transport investment and house prices. J. Prop. Valuat. Invest. 1998, 16, 144-158. [CrossRef]

35. Hsu, C.; Guo, S. CBD Oriented Commuters' Mode and Residential Location Choices in an Urban Area with Surface Streets and Rail Transit Lines. J. Urban Plan. Dev. 2006, 132, 235-246. [CrossRef]

36. Ozmen-Ertekin, D.; Ozbay, K.; Holguin-Veras, J. Role of Transportation Accessibility in Attracting New Businesses to New Jersey. J. Urban Plan. Dev. 2007, 133, 138-149. [CrossRef]

37. Amato, F.; Martellozzo, F.; Nolè, G.; Murgante, B. Preserving cultural heritage by supporting landscape planning with quantitative predictions of soil consumption. J. Cult. Herit. 2017, 23, 44-54. [CrossRef]

38. Di Palma, F.; Amato, F.; Nolè, G.; Martellozzo, F.; Murgante, B. A SMAP Supervised Classification of Landsat Images for Urban Sprawl Evaluation. ISPRS Int. J. Geo-Inf. 2016, 5, 109. [CrossRef]

39. Amato, F.; Pontrandolfi, P.; Murgante, B. Supporting planning activities with the assessment and the prediction of urban sprawl using spatio-temporal analysis. Ecol. Inform. 2015, 30, 365-378. [CrossRef]

40. Amato, F.; Maimone, B.A.; Martellozzo, F.; Nolè, G.; Murgante, B. The Effects of Urban Policies on the Development of Urban Areas. Sustainability 2016, 8, 297. [CrossRef]

41. Monkkonen, P.; Ronconi, L. Land Use Regulations, Compliance and Land Markets in Argentina. Urban Stud. 2013, 50, 1951-1969. [CrossRef]

42. Barton, E.S. Land rent and housing policy: A case study of the San Francisco Bay area rental housing market. Am. J. Econ. Sociol. 2011, 70, 845-873. [CrossRef] [PubMed]

43. Rebelo, E.M. Land economic rent computation for urban planning and fiscal purposes. Land Use Policy 2009, 26, 521-534. [CrossRef] 